\title{
Regenerative agriculture: merging farming and natural resource conservation profitably
}

\author{
Claire E LaCanne ${ }^{1}$, Jonathan G Lundgren ${ }^{\text {Corresp. } 2}$ \\ 1 Natural Resource Management Department, South Dakota State University, Brookings, SD, USA \\ 2 Ecdysis Foundation, Estelline, SD, USA \\ Corresponding Author: Jonathan G Lundgren \\ Email address: jgl.entomology@gmail.com
}

Most cropland in the U.S. is characterized by large monocultures, whose productivity is maintained through a strong reliance on costly tillage, external fertilizers, and pesticides ( Schipanski et al., 2016 ). Despite this, farmers have developed a regenerative model of farm production that promotes soil health and biodiversity, while producing nutrient-dense farm products profitably. Little work has focused on the relative costs and benefits of novel regenerative farming operations, which necessitates studying in situ, farmer-defined best management practices. Here, we evaluate the relative effects of regenerative and conventional corn production systems on pest management services, soil conservation, and farmer profitability and productivity throughout the Northern Plains of the United States. Regenerative farming systems provided greater ecosystem services and profitability for farmers than an input-intensive model of corn production. Pests were 10fold more abundant in insecticide-treated corn fields than on insecticide-free regenerative farms, indicating that farmers who proactively design pest-resilient food systems outperform farmers that react to pests chemically. Regenerative fields had $29 \%$ lower grain production but $78 \%$ higher profits over traditional corn production systems. Profit was positively correlated with the particulate organic matter of the soil, not yield. These results provide the basis for dialogue on ecologically based farming systems that could be used to simultaneously produce food while conserving our natural resource base: two factors that are pitted against one another in simplified food production systems. To attain this requires a systems-level shift on the farm; simply applying individual regenerative practices within the current production model will not likely produce the documented results. 
1 A submission for PeerJ

2 Word count: 2177

3 Regenerative agriculture: merging farming and natural resource conservation profitably.

4 Claire E. LaCanne ${ }^{1,2,3}$ and Jonathan G. Lundgren ${ }^{2, *}$

$5 \quad{ }^{1}$ Natural Resource Management Department, South Dakota State University, Brookings, SD, USA, 57007

$6 \quad{ }^{2}$ Ecdysis Foundation, Estelline, SD, USA, 57234

$7{ }^{3}$ Current address. Rice County Extension Office, University of Minnesota, 1900 Fairground Drive \#17,

8 Faribault, MN, 55021

$9 \quad{ }^{*}$ Address correspondence to

10 Dr. Jonathan Lundgren

11 Ecdysis Foundation

$1246958188^{\text {th }}$ Street

13 Estelline, SD, 57234, USA

14 Phone: 605-695-9878

15 E-mail: igl.entomology@gmail.com

16 Web: www.ecdysis.bio 
17 Abstract. Most cropland in the U.S. is characterized by large monocultures, whose productivity is maintained through a strong reliance on costly tillage, external fertilizers, and pesticides (Schipanski et al., 2016). Despite this, farmers have developed a regenerative model of farm production that promotes soil health and biodiversity, while producing nutrient-dense farm products profitably. Little work has focused on the relative costs and benefits of novel regenerative farming operations, which necessitates studying in situ, farmer-defined best management practices. Here, we evaluate the relative effects of regenerative and conventional corn production systems on pest management services, soil conservation, and farmer profitability and productivity throughout the Northern Plains of the United States.

Regenerative farming systems provided greater ecosystem services and profitability for farmers than an input-intensive model of corn production. Pests were 10-fold more abundant in insecticide-treated corn fields than on insecticide-free regenerative farms, indicating that farmers who proactively design pestresilient food systems outperform farmers that react to pests chemically. Regenerative fields had $29 \%$ lower grain production but $78 \%$ higher profits over traditional corn production systems. Profit was positively correlated with the particulate organic matter of the soil, not yield. These results provide the basis for dialogue on ecologically based farming systems that could be used to simultaneously produce food while conserving our natural resource base: two factors that are pitted against one another in simplified food production systems. To attain this requires a systems-level shift on the farm; simply applying individual regenerative practices within the current production model will not likely produce the documented results. 
Introduction. Development of synthetic fertilizers, hybrid crops, genetically modified crops, and policies that decouple farmer decisions from market demands all helped create a modern food production system which reduces the diversity of foods that are produced (Fausti \& Lundgren, 2015; Pretty, 1995). This simplification of our food system contributes to climate change (Carlsson-Kanyama \& Gonzalez, 2009), rising pollution (Beman et al., 2011; Morrissey et al., 2015), biodiversity loss (Butler et al., 2007; Landis et al., 2008), and damaging land use changes (Johnston, 2014; Wright \& Wimberly, 2013) that affect the sustainability, profitability and resilience of farms (Schipanski et al., 2016). Farmers experience the highest suicide rate of any profession in the United States, a rate nearly five-fold higher than the general public (McIntosh et al., 2016); the driving depression rates are related to conventional production practices (Beard et al., 2014). The scale of our food production system provides opportunities for solving some of these planetary scale problems (Lal, 2004; Teague et al., 2016), but requires a systems-level shift in the values and goals of our food production system that de-prioritizes solely generating high yields toward one that produces higher quality food while conserving our natural resource base.

The goal of regenerative farming systems (Rodale, 1983) is to increase soil quality and biodiversity in

farmland while producing nourishing farm products profitably. Unifying principles consistent across regenerative farming systems include 1) abandoning tillage (or actively rebuilding soil communities the farm, and 4) integrating livestock and cropping operations on the land. Further characterization of a regenerative system is problematic because of the myriad combinations of farming practices that comprise a system targeting the regenerative goal. Other comparisons of conventional agriculture with alternative agriculture schemes do not compare in situ best management practices developed by

58 farmers, and frequently ignore a key driver to decision making on farming operations: the examined

59 systems' relative net profit to the farmer (De Ponti et al., 2012). 
60 Materials and Methods. Corn (Zea mays L.) was selected for our study due to its pre-eminence as a

61 food crop in North America and globally. Corn is planted on 39.9\% of all crop acres (NASS, 2017), or 4.8\%

62 (37.1 million ha) of the terrestrial land surface of the contiguous 48 states. In 2012, it generated 30.3\%

63 ( $\$ 64,319$ billion) of all gross crop value in the U.S. (NASS, 2017). Nearly $100 \%$ of cornfields are treated

64 annually with insecticides (NASS, 2017). We used a matrix of specific production practices (Table 1) to

65 define each farm into one of two systems (regenerative or conventional). The most regenerative systems

66 ( $n=40$ fields on 10 farms) used mixed multispecies cover crops (ranging from 2-40 plant species), were

67 never-till, used no insecticides, and grazed livestock on their cropland. The most conventional farms

68 practiced tillage at least annually (36 fields on 8 farms), applied insecticides (as GM insect-resistant

69 varieties and neonicotinoid seed treatments), and left their soil bare aside from the cash crop.

70 Soil organic matter, insect pest populations, and corn yield and profit were assessed for each field.

71 Soil cores ( $8.5 \mathrm{~cm}$ deep, $5 \mathrm{~cm}$ in diameter; $30 \mathrm{~g}$ of soil each; $\mathrm{n}=4$ samples per field that were made a

72 composite sample; only one field was sampled per farm- selected by the producer- and two farms were

73 omitted due to adverse weather during the sampling event) were collected at least $10 \mathrm{~m}$ from one

74 another during anthesis. Samples were cleaned of plant residue, ground, and dried to constant weight at

$75105^{\circ} \mathrm{C}$. Particulate soil organic matter (POM) was determined by screening each sample (soaked in

$765 \mathrm{~g} \mathrm{~L}^{-1}$ aqueous hexametaphosphate) through 500 um (course POM) and 53 um (fine POM) sieves and

77 then applying the loss on ignition (LOI) technique (Davies, 1974). Insect pests were enumerated through

78 dissections of all aboveground plant tissues (25 plants per field). Major pests of corn (rootworm adults,

79 caterpillar pests, and aphids) are all present in cornfields at this crop developmental stage (Lundgren et

80 al., 2015), and this was substantiated in the observations in this study as well. Yields were gathered from

81 three randomly selected $3.5 \mathrm{~m}$ sections of row from each field. Gross revenue for each field were

82 considered as yield and return on grain, and additional revenue streams (e.g., animal weight gain

83 resulting from grazing). Total direct costs for each field were calculated based on the costs of corn seed, 
84 cover crop seed, drying/cleaning grain, crop insurance, tillage, planting, fertilizers, pesticides, and

85 irrigation.

86 Results and Discussion. Insect pest populations were more than 10 fold higher on the insecticide-

87 treated farms than on the insecticide-free regenerative farms (ANOVA; $F_{1,77}=13.52, P<0.001$; Figure 1 ).

88 Pest populations were numerically dominated by aphids, but each of the individual pest species followed

89 the same pattern of the aggregated data; none of these pests were at economically damaging levels, as

90 observed in other work in the region (Hutchison et al., 2010; Lundgren et al., 2015). Pest problems in

91 agriculture are often the product of low biodiversity and simple community structure on numerous

92 spatial scales (Tscharntke et al., 2012). Hundreds of invertebrate species have been inventoried from

93 cornfields of the Northern Plains of the U.S. (Lundgren et al., 2015; Welch \& Lundgren, 2016), but these

94 communities represent only $25 \%$ of the insect species that lived in ancestral habitats (e.g., prairie) that

95 cornfields replaced in this region (Schmid et al., 2015). Pest abundance is lower in cornfields that have

96 greater insect diversity, enhanced biological network strength and greater community evenness

97 (Lundgren \& Fausti, 2015). Suggested mechanisms to explain how invertebrate diversity and network

98 interactions reduce pests include predation (Letourneau et al., 2009), competition (Barbosa et al., 2009),

99 and other processes that may not be easily predicted. What practices foster diversity in agroecosystems?

100 In our studies, farmers that replaced insecticide use with agronomic forms of plant diversity invariably

101 had fewer pest problems than those with strict monocultures. Reducing insect diversity and relying solely

102 on insecticide use establishes a scenario whereby pests persist and resurge through adaptation, as was

103 observed by our forebears (Perkins, 1982; Stern et al., 1959). Applying winter cover crops (Lundgren \&

104 Fergen, 2011), lengthening crop rotations (Bullock, 1992), diversifying field margins using conservation

105 mixes (Haaland et al., 2011), and allowing or promoting non-crop plants between crop rows (Khan et al.,

106 2006) are other agronomically sound practices that regenerative farmers successfully apply to improve

107 the resilience of their system to pest proliferation. 
Despite having lower grain yields, the regenerative system was nearly twice as profitable as the conventional corn farms (ANOVA; $F_{1,70}=14.35, P<0.001$; Figure 2). Regenerative farms produced $29 \%$ less corn grain than conventional operations ( $8481 \pm 684 \mathrm{~kg} / \mathrm{ha}$ vs. $11,884 \pm 648 \mathrm{~kg} / \mathrm{ha}$; ANOVA;

$\left.111 F_{1,70}=8.39, P=0.01\right)$. Yield reductions are commonly reported in more ecologically based food production systems relative to conventional systems (De Ponti et al., 2012). However, only $4 \%$ of calories produced as corn grain is eaten directly by humans, and almost none is consumed as grain. Thirty-six percent of grain is fed to livestock (NASS, 2017), and corn-fed beef contains only $13 \%$ of the total calories produced by corn grain. Two ways that regenerative systems could increase the human food produced per ha in cornfields would be to increase the diversity of livestock on the field, or increasing the duration of grazing current stock. The relative profitability in the two systems was driven by the high seed and fertilizer costs that conventional farms incurred (32\% of the gross income went into these inputs on conventional fields, versus only $12 \%$ in regenerative fields), and the higher revenue generated from grain and other products produced (e.g., meat production) on the regenerative corn fields (Figure 2). The high seed costs on conventional farms are largely attributable to premiums paid by farmers for prophylactic insecticide traits (no insecticide was applied as spray on these fields), whose value is questionable due to pest resistance and persistent low abundance for some targeted pests in the Northern Plains (Hutchison et al., 2007; Krupke et al., 2017). Regenerative farmers reduced their fertilizer costs by including legumebased cover crops on their fields during the fallow period (Ebelhar et al., 1984), adopting no-till practices (Lal et al., 2007), and grazing the crop field with livestock (Russelle et al., 2010). They also received higher value for their crop by receiving an organic premium, by selling their grain directly to consumers as seed livestock).

130 The profitability of a corn field was not related to grain yields $\left(F_{1,70}<0.001 ; P=0.98 ; r^{2}<0.01\right.$; profit $=-0.0006[$ yield $]+1274)$, but was positively correlated with the level of POM in the soil, and 
presented here are reported in Table 2). Organic matter is considered by some as the basis for

productivity in the soil (Karlen et al., 1997; Tiessen et al., 1994), and soils with high SOM typically have

lower bulk density. SOM increases water infiltration rates, and supports greater microbial and animal

abundance and diversity (Lehman et al., 2015). The components of POM are the labile portion of this

SOM, and are frequently used to study the effects of management-based differences in SOM

(Cambardella \& Elliott, 1992). The only way to generate SOM in situ in cropland is through fostering

biology, which inherently is driven by plant communities through sequestration of $\mathrm{CO}_{2}$ from the

2006; Kuo et al., 1997), and cycling plant residue through livestock (Tracy \& Zhang, 2008) all enhance this process, and all are important practices used in regenerative food systems that raise POM in the soil.

Conclusions. The farmers themselves have devised an ecologically based production system

1) By promoting soil biology and organic matter and biodiversity on their farms, regenerative farmers required fewer costly inputs like insecticides and fertilizers, and managed their pest populations more effectively.

2) Soil organic matter was a more important driver of proximate farm profitability than yields were, in part because the regenerative farms marketed their products differently or had a diversified income stream from a single field. 
157 M. La Vallie, A. Leiferman, J. Lundgren, A. Martens, C. Mogren, K. Nemec, A. Nikolas, J. Pecenka, G. Schen,

158 C. Snyder, \& K. Weathers assisted field work. R. Conser, M. Entz, C. Morrissey, \& R. Teague provided

159 comments on earlier drafts. M. Longfellow and L. Hesler identified invertebrates. Mention of trade names

160 or commercial products in this publication does not imply recommendation or endorsement by South

161 Dakota State University or Ecdysis Foundation.

\section{References}

Barbosa, P., Hines, J., Kaplan, I., Martinson, H., Szczepaniec, A., \& Szendrei, Z. (2009) Associational resistance and susceptibility: having right or wrong neighbors. Annual Review of Ecology, Evolution \& Systematics, 40, 1-20.

Beard, J.D., Umbach, D.M., Hoppin, J.A., Richards, M., Alavanja, M.C.R., Blair, A., Sandler, D.P., \& Kamel, F. (2014) Pesticide exposure and depression among male private pesticide applicators in the agricultural health study. Environmental Health Perspectives, 122, 984-991.

Beman, J.M., Chow, C.-E., King, A.L., Feng, Y., Fuhrman, J.A., Andersson, A., Bates, N.R., Popp, B.N., \& Hutchings, D.A. (2011) Global declines in oceanic nitrification rates as a consequence of ocean acidification. Proceedings of the National Academy of Sciences of the U.S.A., 108, 208-213.

Bullock, D.G. (1992) Crop rotation. Critical Reviews in Plant Sciences, 11, 309-326.

176 Cambardella, C.A. \& Elliott, E.T. (1992) Particulate soil organic-matter changes across a grassland cultivation sequence. Soil Science Society of America Journal, 56, 777-783.

Carlsson-Kanyama, A. \& Gonzalez, A.D. (2009) Potential contributions of food consumption patterns to climate change. The American Journal of Clinical Nutrition, 89, 1704S-1709S. 
182

De Ponti, T., Rijk, B., \& Van Ittersum, M.K. (2012) The crop yield gap between organic and conventional agriculture. . Agricultural Systems, 108, 1-9.

Ding, G., Liu, X., Herbert, S., Novak, J., Amarasiriwardena, D., \& Xing, B. (2006) Effect of cover crop management on soil organic matter. Geoderma, 130, 229-239.

Ebelhar, S.A., Frye, W.W., \& Blevins, R.L. (1984) Nitrogen from legume cover crops for no-tillage corn. Agronomy Journal, 76, 51-55.

Fausti, S.W. \& Lundgren, J.G. (2015) The causes and unintended consequences of a paradigm shift in corn production practices. Environmental Science \& Policy, 52, 41-50.

Haaland, C., Naisbit, R.E., \& Bersier, L.-F. (2011) Sown wildflower strips for insect conservation: a review. Insect Conservation and Diversity, 4, 60-80.

Hutchison, W.D., Burkness, E., Moon, R., Leslie, T., Fleischer, S., Abrahamson, M., Hamilton, K., Steffey, K., \& Gray, M. (2007). Evidence for regional suppression of European corn borer populations in Bt maize in the midwestern U.S.: Analysis of long-term time series' from three states. In XVI International Plant Protection Congress. , pp. 512-513, Glasgow, Scotland.

Hutchison, W.D., Burkness, E.C., Mitchell, P.D., Moon, R.D., Leslie, T.W., Fleischer, S.J., Abrahamson, M., Hamilton, K.L., Steffey, K.L., Gray, M.E., Hellmich, R.L., Kaster, L.V., Hunt, T.E., Wright, R.J., Pecinovsky, K., Rabaey, T.L., Flood, B.R., \& Raun, E.S. (2010) Areawide suppression of European corn borer with Bt maize reaps savings to non-Bt maize grower. Science, 330, 222-225.

Johnston, C.A. (2014) Agricultural expansion: land use shell game in the U.S. Northern Plains. Landscape Ecology, 29, 81-95.

Karlen, D.L., Mausbach, M.J., Doran, J.W., Cline, R.G., Harris, R.F., \& Schuman, G.E. (1997) Soil quality: a concept, definition, and framework for evaluation. Soil Science Society of America Journal, 61, 4-10.

Khan, Z.R., Pickett, J.A., Wadhams, L.J., Hassanali, A., \& Midega, C.A.O. (2006) Combined control of Striga hermonthica and stemborers by maize-Desmodium spp. intercrops. Crop Protection, 25, 989-995. 
206 Krupke, C.H., Holland, J.D., Long, E.Y., \& Eitzer, B.D. (2017) Planting of neonicotinoid-treated maize poses

207 risks for honey bees and other non-target organisms over a wide area without consistent crop yield

208 benefit. Journal of Applied Ecology, in press.

209 Kuo, S., Sainju, U.M., \& Jellum, E.J. (1997) Winter cover crop effects on soil organic carbon and

210 carbohydrate in soil. Soil Science Society of America Journal, 61, 145-152.

211 Lal, R. (2004) Soil carbon sequestration impacts on global climate change and food security. Science, 304, $212 \quad 1623$.

213 Lal, R., Reicosky, D.C., \& Hanson, J.D. (2007) Evolution of the plow over 10,000 years and the rationale for 214 no-till farming. Soil \& Tillage Research, 93, 1-12.

215 Landis, D.A., Gardiner, M.M., van der Werf, W., \& Swinton, S.M. (2008) Increasing corn for biofuel 216 production reduces biocontrol services in agricultural landscapes. Proceedings of the National $217 \quad$ Academy of Sciences, 105, 20552-20557.

218 Lehman, R.M., Cambardella, C.A., Stott, D.E., Acosta-Martinez, V., Manter, D.K., Buyer, J.S., Maul, J.E., 219 Smith, J.L., Collins, H.P., Halvorson, J.J., Kremer, R.J., Lundgren, J.G., Ducey, T.F., Jin, V.L., \& Karlen, D.L. 220 (2015) Understanding and enhancing soil biological health: The solution for reversing soil 221 degradation. Sustainability, 7, 988-1027.

Letourneau, D.K., Jedlicka, J.A., Bothwell, S.G., \& Moreno, C.R. (2009) Effects of Natural Enemy Biodiversity on the Suppression of Arthropod Herbivores in Terrestrial Ecosystems. Annual Review of Ecology, Evolution, and Systematics, 40, 573-592.

Lundgren, J.G. \& Fausti, S.W. (2015) Trading biodiversity for pest problems. Science Advances, 1, e1500558.

Lundgren, J.G. \& Fergen, J.K. (2011) Enhancing predation of a subterranean insect pest: A conservation benefit of winter vegetation in agroecosystems. Applied Soil Ecology, 51, 9-16. 
229

230

Lundgren, J.G., McDonald, T.M., Rand, T.A., \& Fausti, S.W. (2015) Spatial and numerical relationships of arthropod communities associated with key pests of maize. Journal of Applied Entomology, 136, 446456.

McIntosh, W.L.W., Spies, E., Stone, D.M., Lokey, C.N., Trudeau, A.-R., \& Bartholow, B. (2016) Suicide rates by occupational group- 17 states, 2012. MMWR Morbity and Mortality Weekly Report 2016, 65, 641645.

Morrissey, C.A., Mineau, P., Devries, J.H., Sanchez-Bayo, F., Liess, M., Cavallaro, M.C., \& Liber, K. (2015) Neonicotinoid contamination of global surface waters and associated risk to aquatic invertebrates: A review. Environment International, 74, 291-303.

NASS (2017) National Agriculture Statistics Service. USDA.

Perkins, J.H. (1982) Insects, Experts, and the Insecticide Crisis. Plenum Press, New York.

Pikul, J.L., Jr., Osborne, S.E., Ellsbury, M.M., \& Riedell, W.E. (2007) Particulate organic matter and waterstable aggregation of soil under contrasting management. Soil Science Society of America Journal, 71, 766-776.

Pretty, J.N. (1995) Regenerating Agriculture: Policies and practice for sustainability and self-reliance. Joseph Henry Press, Washington, D.C.

Rodale, R. (1983) Breaking new ground: the search for a sustainable agriculture. The Futurist, 17, 15-20.

Russelle, M.P., Entz, M.H., \& Franzluebbers, A.J. (2010) Reconsidering integrated crop-livestock systems in North America. Agronomy Journal, 99, 325-334.

Schipanski, M.E., MAcDonald, G.K., Rosenzweig, S., Chappell, M.J., Bennett, E.M., Kerr, R.B., Blesh, J., Crews, T.E., Drinkwater, L.E., Lundgren, J.G., \& Schnarr, C. (2016) Realizing resilient food systems. Bioscience, 66, 600-610.

Schmid, R.B., Lehman, R.M., Brözel, V.S., \& Lundgren, J.G. (2015) Gut bacterial symbiont diversity within beneficial insects linked to reductions in local biodiversity. Annals of the Entomological Society of America, 108, 993-999. 
254 Six, J., Elliott, E.T., \& Paustian, K. (1999) Aggregate and soil organic matter dynamics under conventional

255 and no-tillage systems. Soil Sci. Soc. Am. J. 63, 1350-1358. Soil Science Society of America Journal, 63,

$256 \quad 1350-1358$.

257 Stern, V.M., Smith, R.F., van den Bosch, R., \& Hagen, K.S. (1959) The integrated control concept. Hilgardia, $258 \quad 29,81-101$.

259 Teague, W.R., Apfelbaum, S., Lal, R., Kreuter, U.P., Rowntree, J., Davies, C.A., \& Wang, F. (2016) The role of 260 ruminants in reducing agriculture's carbon footprint in North America. . Journal of Soil and Water 261 Conservation, 71, 156-164.

262 Tiessen, H., Cuevas, E., \& Chacon, P. (1994) The role of soil organic matter in sustaining soil fertility. $263 \quad$ Nature, 371, 783-785.

264 Tracy, B.F. \& Zhang, Y. (2008) Soil compaction, corn yield response, and soil nutrient pool dynamics within 265 an integrated crop-livestock system in Illinois. Crop Science, 48, 1211-1218.

266 Tscharntke, T., Clough, Y., Wanger, T.C., Jackson, L., Motzke, I., Perfecto, I., Vandermeer, J., \& Whitbread, 267 A. (2012) Global food security, biodiversity conservation and the future of agricultural intensification. 268 Biological Conservation, 151, 53-59.

269 Welch, K.D. \& Lundgren, J.G. (2016) An exposure-based, ecology-driven framework for selection of 270 indicator species for insecticide risk assessment. Food Webs, 9, 46-54.

271 Wright, C.K. \& Wimberly, M.C. (2013) Recent land use change in the Western Corn Belt threatens 272 grasslands and wetlands. Proceedings of the National Academy of Sciences of the U.S.A., 110, 4134$273 \quad 4319$. 
274 Figure 1. Insecticide-treated cornfields had higher pest abundance than untreated, regenerative

cornfields. Values presented are mean \pm SEM total pests (corn rootworm adults, European corn borers, Western bean cutworm, other caterpillars, and aphids) per $\mathrm{m}^{2}$, and were assessed during corn anthesis. The systems were regarded as best-management practices for the sampled region by the farmers themselves. All conventional farms planted neonicotinoid-treated, Bt corn seed to prophylactically reduce pests, and some cornfields were also sprayed with insecticides. Regenerative farms included $>3$ of the following practices: use of a multispecies cover crop, abandonment of insecticide, abandonment of tillage, and the cropland was grazed, etc. Pest abundance was significantly different in the two systems ( $a=0.05 ; n=39$ regenerative cornfields and 40 conventional cornfields).

Figure 2. Regenerative corn fields generate nearly twice the profit of conventionally managed corn fields. The heights of the bars represent average gross profits across all 40 fields (in each treatment). Profit was calculated using direct costs and revenues for each field and excludes any overhead and indirect expenses. Regenerative cornfields implemented three or more practices such as planting a multispecies cover mix, eliminating pesticide use, abandoning tillage, and integrating livestock onto the crop ground. Conventional cornfields used fewer than two of these practices. The regenerative systems had 70\% higher profit than conventional cornfields ( $a=0.05 ; n=36$ fields in each system). Seed drying, corn planting, and cover crop planting are present on the graphs, but were negligible costs.

Figure 3. Corn fields with high particulate organic matter and low bulk density in the soil have greater profits. Corn fields were managed under either conventional or regenerative systems, and profit was calculated using direct costs and revenues for each field and excludes any overhead and indirect expenses. (general linear regression model; $F_{1,16}=7.84 ; P=0.01 ; r^{2}=0.34 ;$ profit $=29.68[P O M]-66.94$; bulk density; $F_{1,19}=5.23 ; P=0.03 ; r^{2}=0.24$; profit $=-975[P O M]+1593$ ) 


\section{Figure 1}

Insecticide-treated cornfields had higher pest abundance than untreated, regenerative cornfields.

Values presented are mean \pm SEM total pests (corn rootworm adults, European corn borers, Western bean cutworm, other caterpillars, and aphids) per $\mathrm{m}^{2}$, and were assessed during corn anthesis. The systems were regarded as best-management practices for the sampled region by the farmers themselves. All conventional farms planted neonicotinoid-treated, Bt corn seed to prophylactically reduce pests, and some cornfields were also sprayed with insecticides. Regenerative farms included $>3$ of the following practices: use of a multispecies cover crop, abandonment of insecticide, abandonment of tillage, and the cropland was grazed, etc. Pest abundance was significantly different in the two systems $(\alpha=0.05 ; n=39$ regenerative cornfields and 40 conventional cornfields). 


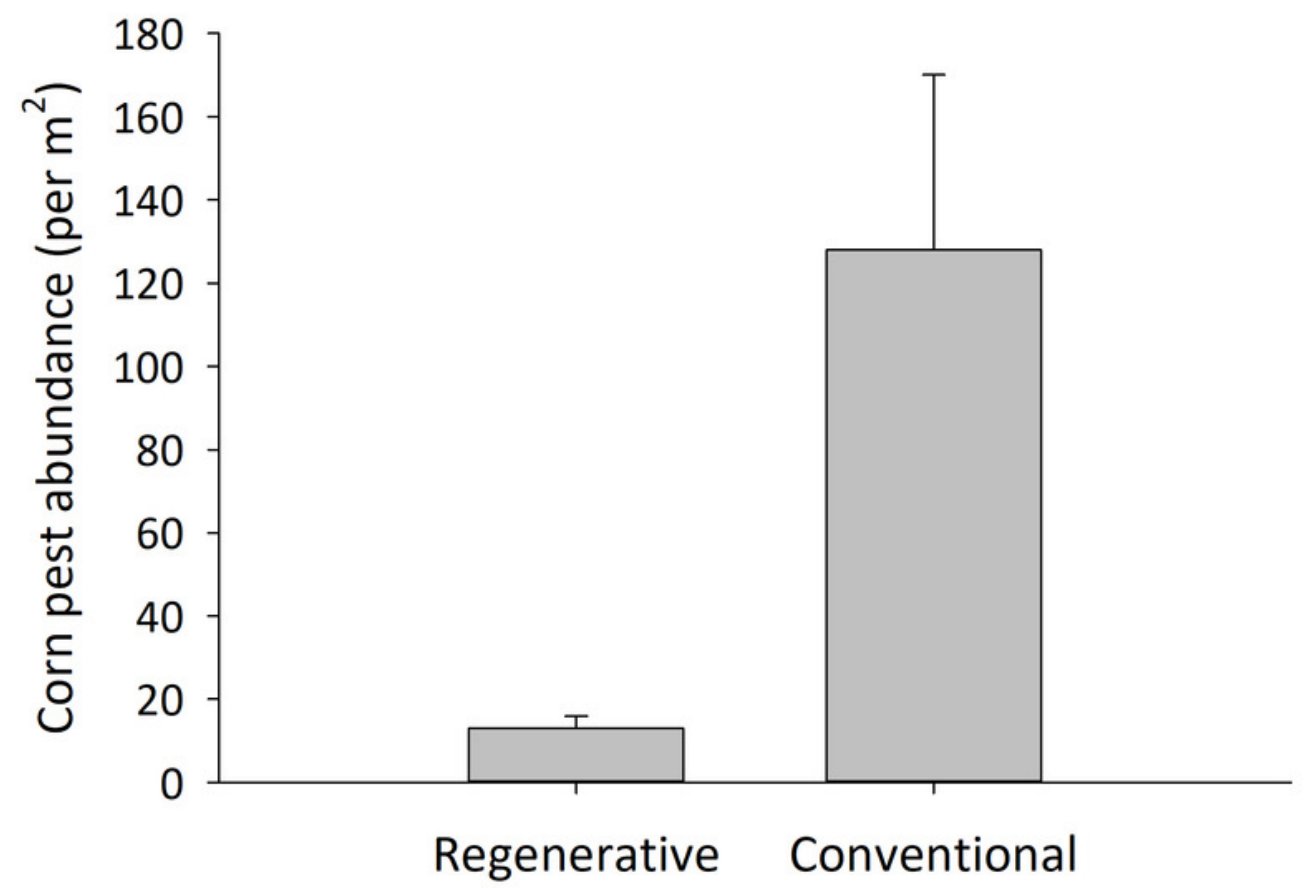




\section{Figure 2}

Regenerative corn fields generate nearly twice the profit of conventionally managed corn fields.

The heights of the bars represent average gross profits across all 40 fields (in each treatment). Profit was calculated using direct costs and revenues for each field and excludes any overhead and indirect expenses. Regenerative cornfields implemented three or more practices such as planting a multispecies cover mix, eliminating pesticide use, abandoning tillage, and integrating livestock onto the crop ground. Conventional cornfields used fewer than two of these practices. The regenerative systems had 70\% higher profit than conventional cornfields ( $\alpha=0.05 ; n=36$ fields in each system). Seed drying, corn planting, and cover crop planting are present on the graphs, but were negligible costs. 


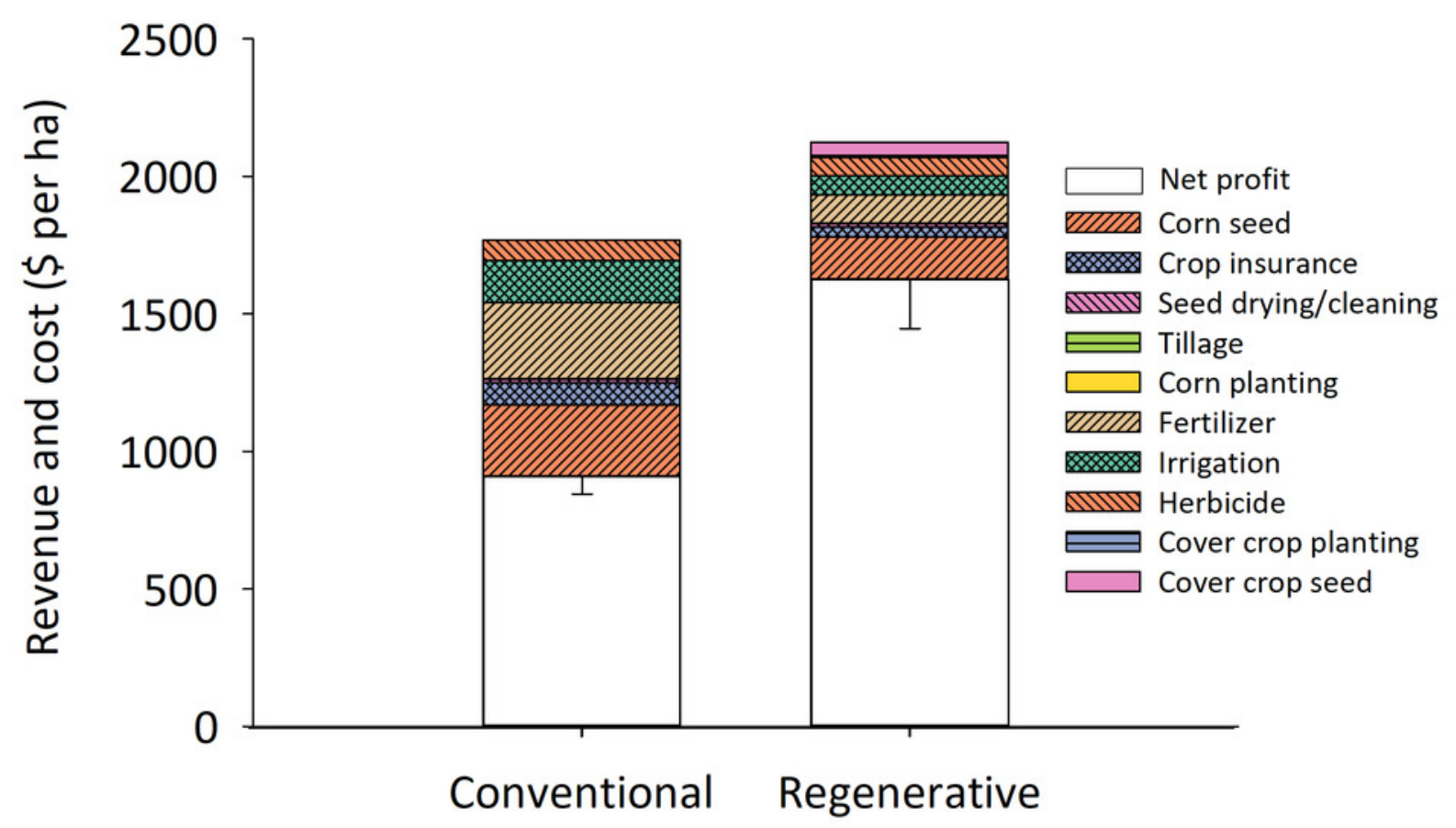




\section{Figure 3}

Corn fields with high particulate organic matter and low bulk density in the soil have greater profits.

Corn fields were managed under either conventional or regenerative systems, and profit was calculated using direct costs and revenues for each field and excludes any overhead and indirect expenses. (general linear regression model; $F_{1,16}=7.84 ; P=0.01 ; r^{2}=0.34$;

profit $=29.68[\mathrm{POM}]-66.94 ;$ bulk density; $F_{1,19}=5.23 ; P=0.03 ; r^{2}=0.24 ;$ profit $=-975[\mathrm{POM}]+$ 1593) 


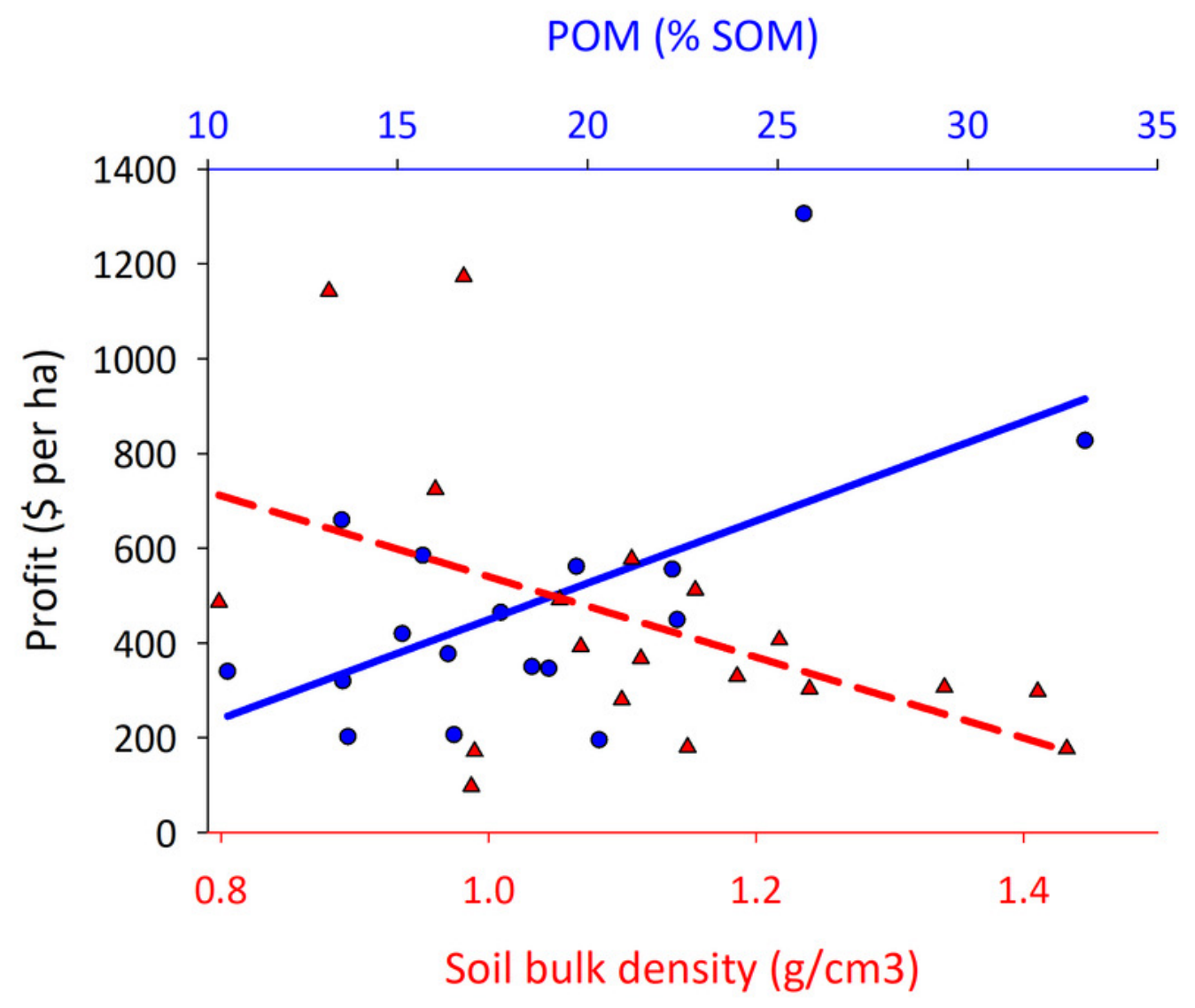




\section{Table $\mathbf{1}$ (on next page)}

Farm characteristics for defining regenerative and conventional systems

Trait matrix used to assign farms to regenerative or conventional corn production systems. The composite rank scores are based on the number of regenerative practices used on a particular farm. Farms whose rank scores are in the top $50 \%$ of farms are considered regenerative (shaded rows); those with rank scores in the lower half are conventional (white rows). To aid interpretation, additional traits of each system could be included in enhanced trait matrices. 
Table 1. Trait matrix used to assign farms to regenerative or conventional corn production systems. The composite rank scores are based on the number of regenerative practices used on a particular farm. Farms whose rank scores are in the top 50\% of farms are considered regenerative (shaded rows); those with rank scores in the lower half are conventional (white rows). To aid interpretation, additional traits of each system could be included in enhanced trait matrices. Organic operations are indicated by an asterisk in the "Reference town" column.

\begin{tabular}{|c|c|c|c|c|c|c|c|}
\hline $\begin{array}{l}\text { Reference } \\
\text { town }\end{array}$ & $\begin{array}{l}\text { Farm locations } \\
\text { (latitude, longitude }\end{array}$ & $\begin{array}{l}\text { Cover } \\
\text { crop } \\
\text { (yes: 1; } \\
\text { no: } 0 \text { ) }\end{array}$ & $\begin{array}{c}\text { Insecticid } \\
\text { e } \\
\text { (no: } 1 ; \\
\text { yes: } 0 \text { ) }\end{array}$ & $\begin{array}{c}\text { Other } \\
\text { pesticide } \\
\text { s } \\
\text { (no: } 1 ; \\
\text { yes: } 0 \text { ) }\end{array}$ & $\begin{array}{c}\text { Tillage } \\
\text { (yes: 1; } \\
\text { no: 0) }\end{array}$ & $\begin{array}{c}\text { Graze } \\
\text { d corn } \\
\text { field } \\
\text { (yes: } \\
\text { 1; no: } \\
0 \text { ) } \\
\end{array}$ & $\begin{array}{c}\text { Composit } \\
\text { e rank } \\
\text { score }\end{array}$ \\
\hline $\begin{array}{l}\text { Bladen, } \\
\text { NE }\end{array}$ & $40.31971,-98.57358$ & yes & no & yes & no & no & 3 \\
\hline $\begin{array}{l}\text { Bladen, } \\
\text { NE }\end{array}$ & $40.33703,-98.56301$ & no & yes & yes & yes & no & 0 \\
\hline York, NE & $40.63054,-97.66534$ & yes & no & yes & no & no & 3 \\
\hline York, NE & $40.97390,-97.49031$ & no & yes & yes & yes & no & 0 \\
\hline $\begin{array}{l}\text { Bismarck, } \\
\text { ND }\end{array}$ & $46.85280,-100.60131$ & yes & no & no & no & yes & 5 \\
\hline $\begin{array}{l}\text { Bismarck, } \\
\text { ND }\end{array}$ & $46.85280,-100.35145$ & no & yes & yes & no & no & 1 \\
\hline $\begin{array}{l}\text { Bismarck, } \\
\text { ND }\end{array}$ & $46.81734,-100.51257$ & yes & no & yes & no & yes & 4 \\
\hline $\begin{array}{l}\text { Bismarck, } \\
\text { ND }\end{array}$ & $47.14250,-100.19720$ & no & yes & yes & no & no & 1 \\
\hline $\begin{array}{l}\text { White, } \\
\text { SD* }\end{array}$ & $44.42572,-96.58806$ & yes & no & no & yes & no & 3 \\
\hline White, SD & $44.41155,-96.60008$ & no & yes & yes & yes & no & 0 \\
\hline $\begin{array}{l}\text { Pipestone } \\
\text {, } \mathrm{MN}^{*}\end{array}$ & $44.11446,-96.32468$ & yes & no & no & yes & no & 3 \\
\hline $\begin{array}{l}\text { Pipestone } \\
\text {, MN }\end{array}$ & $44.12416,-96.36422$ & no & yes & yes & yes & no & 0 \\
\hline $\begin{array}{l}\text { Toronto, } \\
\text { SD }\end{array}$ & $44.59248,-96.57923$ & yes & yes & yes & no & no & 3 \\
\hline $\begin{array}{l}\text { Toronto, } \\
\text { SD }\end{array}$ & $44.57960,-96.58367$ & no & yes & yes & yes & no & 0 \\
\hline Gary, SD* & $44.80565,-96.34708$ & yes & no & no & yes & yes & 4 \\
\hline Gary, SD & $44.80689,-96.35465$ & no & yes & yes & yes & no & 0 \\
\hline $\begin{array}{l}\text { Arlington, } \\
\text { SD }\end{array}$ & $44.41566,-97.18795$ & yes & no & yes & no & yes & 4 \\
\hline $\begin{array}{l}\text { Arlington, } \\
\text { SD }\end{array}$ & $44.42644,-97.25077$ & no & yes & yes & yes & no & 0 \\
\hline $\begin{array}{l}\text { Lake } \\
\text { Norden, } \\
\text { SD }\end{array}$ & $44.58976,-97.08649$ & yes & yes & yes & no & yes & 3 \\
\hline $\begin{array}{c}\text { Lake } \\
\text { Norden, } \\
\text { SD }\end{array}$ & $\begin{array}{l}44.55 .6839 \\
-97.243820\end{array}$ & no & yes & yes & yes & no & 0 \\
\hline
\end{tabular}




\section{Table 2 (on next page)}

Soil organic matter on regenerative and conventional corn farms.

Shaded rows represent regenerative corn farms. 
Table 2. Soil organic matter on regenerative and conventional corn farms. Shaded rows represent regenerative corn farms.

\begin{tabular}{|c|c|c|}
\hline $\begin{array}{l}\text { Reference } \\
\text { town }\end{array}$ & $\begin{array}{c}\text { Farm locations } \\
\text { (latitude, longitude }\end{array}$ & $\mathrm{SOM}(\mathrm{g} / \mathrm{kg})$ \\
\hline $\begin{array}{l}\text { Bladen, } \\
\text { NE }\end{array}$ & 40.31971, -98.57358 & 6.23 \\
\hline $\begin{array}{l}\text { Bladen, } \\
\text { NE }\end{array}$ & 40.33703, -98.56301 & 4.52 \\
\hline York, NE & $40.63054,-97.66534$ & 6.21 \\
\hline York, NE & 40.97390, -97.49031 & 5.55 \\
\hline $\begin{array}{l}\text { Bismarck, } \\
\text { ND }\end{array}$ & $46.85280,-100.60131$ & 4.19 \\
\hline $\begin{array}{l}\text { Bismarck, } \\
\text { ND }\end{array}$ & $46.85280,-100.35145$ & N/A \\
\hline $\begin{array}{l}\text { Bismarck, } \\
\text { ND }\end{array}$ & $46.81734,-100.51257$ & 5.82 \\
\hline $\begin{array}{l}\text { Bismarck, } \\
\text { ND }\end{array}$ & $47.14250,-100.19720$ & 3.85 \\
\hline White, SD & $44.42572,-96.58806$ & N/A \\
\hline White, SD & $44.41155,-96.60008$ & 5.52 \\
\hline $\begin{array}{l}\text { Pipestone, } \\
\text { MN }\end{array}$ & 44.11446, -96.32468 & N/A \\
\hline $\begin{array}{l}\text { Pipestone, } \\
\text { MN }\end{array}$ & $44.12416,-96.36422$ & 4.75 \\
\hline $\begin{array}{l}\text { Toronto, } \\
\text { SD }\end{array}$ & $44.59248,-96.57923$ & 7.60 \\
\hline $\begin{array}{l}\text { Toronto, } \\
\text { SD }\end{array}$ & $44.57960,-96.58367$ & 6.38 \\
\hline Gary, SD & $44.80565,-96.34708$ & 7.53 \\
\hline Gary, SD & $44.80689,-96.35465$ & 7.36 \\
\hline $\begin{array}{l}\text { Arlington, } \\
\text { SD }\end{array}$ & 44.41566, -97.18795 & 8.17 \\
\hline $\begin{array}{l}\text { Arlington, } \\
\text { SD }\end{array}$ & 44.42644, -97.25077 & 8.18 \\
\hline Lake & & 4.56 \\
\hline $\begin{array}{l}\text { Norden, } \\
\text { SD }\end{array}$ & $44.58976,-97.08649$ & \\
\hline $\begin{array}{l}\text { Lake } \\
\text { Norden, } \\
\text { SD }\end{array}$ & $44.55 .6839,-97.243820$ & 6.26 \\
\hline
\end{tabular}

